\title{
CARTOGRAFia IMAginada DA MANGUEIRA ${ }^{\star}$
}

\author{
Carmen Opipari ${ }^{I} \star \star$ Sylvie Timbert ${ }^{I I} \star \star \star$ \\ ${ }^{I}$ Universidade Federal do Rio de Janeiro, Rio de Janeiro, RJ-Brasil \\ ${ }^{\text {II }}$ Universite Nice Sophia Antipolis, Nice - França
}

\section{RESUMO}

Propomos nesse artigo percorrer os meandros da pesquisa de campo que realizamos, na cidade do Rio de Janeiro, com crianças moradoras do morro da Mangueira e integrantes de sua Escola de Samba. Focamos os desdobramentos teóricos forjados na elaboração coletiva de uma metodologia de pesquisa na qual, tendo a imagem como suporte e objeto de reflexão, deixamo-nos guiar pelos percursos que fizemos com algumas dessas crianças na montagem de dispositivos (desenhos, histórias e vídeo) que permitiram traçar uma cartografia imaginada da Mangueira. Aprendizes de cartógrafos, seguimos as crianças, nossos guias, no labirinto de seu morro, deixamo-nos afetar pela intensidade de uma cor, a fragilidade de uma palavra, a poesia de uma história, compomos com eles um caleidoscópio, sempre precário, prestes a balançar na direção de outras imagens. Palavras-chave: criança; favela; cartografia; violência; imagem.

\section{IMAGINed CARTOGRAPHY OF MANgUeIRA}

\begin{abstract}
We purpose in this article go through the ins and outs of the field research we did, in the city of Rio de Janeiro, with children living in favela of Mangueira and members of her Samba School. Focus on theoretical developments in forged a collective research methodology in which, having the image as support and subject of a thorough investigation, we let ourselves be guided by routes that we did with some of these children in the assembly of dispositifs (drawings, stories and video) that made it possible to trace an imagined cartography of Mangueira. Apprentices of cartographers, we followed the children, our guides, in the maze of its favela, we let us be affected by the intensity of a color, the fragility of a word, the poetry of a story, compose with them a kaleidoscope, always precarious, about to swing in the direction of other images.

Keywords: child; favela; cartography; violence; image.

$\star$ Pesquisa realizada com o apoio do CNPq e da Faperj através da concessão de bolsa de pós-doutorado.

$\star \star$ Possui graduação em Ciências Sociais pela Universidade de São Paulo, mestrado e doutorado em Antropologia Social na Ecole des Hautes Etudes en Sciences Sociales em Marselha, pósdoutorado em Comunicação na Universidade Federal do Rio de Janeiro.

E-mail: carmenopipari@hotmail.com

$\star \star \star$ Possui graduação em Lettres modernes: Cinéma pela Université Sorbonne Nouvelle, mestrado em Arts du Spectacle Cinéma pela Université Sorbonne Nouvelle, doutorado em Philosophie pela Universite Nice Sophia Antipolis e pós-doutorado em Antropologia pela Universidade Federal do Rio de Janeiro. Atualmente é membro do Comité de rédaction de Chimères.

E-mail: sylvietimbert@hotmail.com
\end{abstract}


Nosso primeiro contato com a Mangueira ${ }^{1}$ ocorreu em 2004, num dos trailers instalados sob o viaduto, ao pé do morro, em frente à quadra da Escola de samba. "Você conhece a sopa de ervilha da Cida?". Apenas o tempo de pronunciarmos um tímido "não" e o homem, que comia ali em pé a tal iguaria, já colocava sua colher na boca de uma e da outra. Hum...

Compartilhar, experimentar, sentir.

Com o tempo, passamos à mesa de uma outra birosca. "A Mangueira tá muito metida!", "A Mangueira levou um prejuízo na última operação", "Eu sou Mangueira!”, “Aquele pessoal não é Mangueira!". Uma certa "Mangueira”, tantas vezes evocada ali, parecia abrigar conexões que escapavam ao discurso majoritário sobre a violência no morro, sobre o papel ocupado pela Escola de samba.

Se pela sua origem histórica e sociocultural, morro e Escola de Samba de Mangueira fundem-se, num primeiro nível, nessa evocação "Mangueira", num segundo nível, a Escola de samba adota progressivamente um ponto de vista distanciado: para ela, o morro torna-se "o outro" para o qual estão voltados os diversos projetos sociais que ela organiza a partir dos anos 1990 contando com subvenções de empresas públicas e privadas. "Mangueira", nesse contexto, torna-se uma marca difundida e negociada pela Escola de samba. Uma grande parte desses projetos, dirigidos aos jovens e crianças do morro, transformam-nos num elemento fundamental do jogo de representações que podem ser (re-)produzidas. Num terceiro nível, a Escola de samba opõem-se frontalmente ao morro, estigmatizado como espaço da contravenção e do tráfico de drogas, dominado por uma facção criminosa que lhe impõe um "dono". Essas relações estabelecidas entre morro e Escola de samba, submetidas a um discurso dominante que tende a pacificar as dissidências e os conflitos, cria para um tecido social complexo uma trama simplista em que a violência seria abordada segundo uma divisão qualificada, de maneira recorrente, por duas figuras fechadas em si-mesmas: ser "do bem" ou ser "do mal". Como indica Patrícia Birman (2003, p. 69, tradução nossa), a espetacularização da violência pela mídia oferece as imagens dessa bi-polaridade que ordena uma compreensão tranquilizadora da própria sociedade:

Esses espetáculos da violência fornecem as imagens plausíveis de uma ordem do mundo que se normaliza aos poucos. [...] Seguindo princípios até então dificilmente alteráveis, esses espetáculos compõem uma verdadeira cosmologia na qual confrontam-se o bem e o mal. [...] Através deles forja-se uma imagem da sociedade cujo eixo estruturante é a violência.

Oposição, portanto, sob o modo de uma exclusão radical, de dois polos supostamente homogêneos: o morro da Mangueira, locus da violência, aproximando-se do "mal", e a Escola de samba de Mangueira, tradicional e engajada nos projetos sociais, reservando-se o polo do "bem". Por outro lado, como indica Paulo Vaz (2005), a imagem da cidade em guerra, violenta e assustadora, utilizada pela mídia, participa de uma estratégia de retórica por meio da qual a audiência 
torna-se um "nós" vítima potencial de um "eles" aterrorizante e desumano corporificado pelo bandido, traficante, criminoso. Privilegiando certos sofrimentos "como valendo pelo de todos", a constituição desse "nós" da vítima virtual exclui o sofrimento dos moradores de favela que, pertencendo ao mesmo contexto social do "eles", são no mais das vezes identificados pela sociedade a estes (VAZ, 2005, p. 95-106). Esta oposição, traduzida no interior da Escola de samba pela construção de uma separação entre um "eles" e um "nós", revela-se insustentável. Por razões evidentes de proximidade, os moradores do morro não podem recusar este "eles" ou condená-lo como sendo um monstro.

Espaço privilegiado para uma escuta flutuante que nos abria a outras percepções: a Mangueira evocada ali na mesa daquela birosca situa-se na transversalidade e na concomitância desses diferentes níveis de relações que se estabelecem entre morro e Escola de samba de Mangueira. Rastrear os meandros dessa Mangueira; deixar-nos afetar pelos olhares e falas menores que desestabilizam o instituído, fazem ranger as dissidências, indicam novos sentidos incessantemente renovados.

Fomos apresentadas pela dona da birosca à presidente da Escola de samba mirim Mangueira do Amanhã. Passamos a frequentar também a quadra da Escola, a participar ali das atividades ligadas ao carnaval e dirigidas às crianças. Pouco a pouco, fomos percebendo que estas estão a uma distância particular do que seriam as imagens oficiais e instituídas. Embora as reproduzam, as crianças se encontram na posição privilegiada de poder experimentar novas articulações. Se elas se tornam em alguns momentos alvo, presa, intrumento ou objeto de várias lógicas em jogo (a criança vitimizada, bandido em potencial, assistida pelos projetos sociais, explorada etc.), nos seus percursos singulares entre morro e Escola de samba, elas se deslocam de maneira menos previsível, ocupando lugares de cruzamentos de pontos de vista, de dobradiças que se abrem sobre novas perspectivas. Tendo a imagem como suporte e objeto de reflexão, deixamo-nos guiar pelos percursos que faríamos com algumas dessas crianças na montagem de dispositivos em que desenhos, histórias e vídeo permitiram traçar uma cartografia imaginada da Mangueira.

\section{TATEAMENTOS, FALHAS E BRECHAS}

Entrevista.

Eu já sei o que vocês vão me perguntar: "como você aprendeu a tocar?" E eu vou dizer: "no começo, só olhando os outros tocarem, depois, o professor pega na nossa mão e ensina a bater assim". Depois vocês vão me perguntar: “onde você mora?" e eu vou dizer: "aqui no morro mesmo, na Mangueira". E por aí vai, não é?

Branco: qualquer questão elaborada previamente pelo pesquisador perde-se num esquecimento repentino.

Assim começa uma entrevista gravada em vídeo com um garoto de 14 anos, percussionista na bateria da Escola de samba mirim Mangueira do Amanhã. $\mathrm{O}$ dispositivo torna-se objeto da própria entrevista. $\mathrm{O}$ garoto a dirige, sai do qua- 
dro, propõe que um amigo entre também em cena. Quando este fala alguma coisa, o garoto nos explica o que o amigo quer "realmente dizer". Estranho jogo de tradução que recorre a todo tipo de clichê para tentar estabelecer uma ponte entre o mundo deles, decretado inacessível para nós, e aquele que nós já conhecemos, o único que poderíamos entender.

Movimento circular girando no vazio: retorno automático ao ponto de partida.

Filmagem numa viela no morro da Mangueira. Após uma entrevista com um menino de 10 anos, começamos a filmá-lo com outras crianças no beco em frente à sua casa. Aprendiz de mestre-sala, ele improvisa com uma garota, que segura um cabo de vassoura em guisa de bandeira, os passos da sua dança. Devemos ficar atentas à passagem de qualquer pessoa por ali. Por vezes temos de abaixar e mesmo desligar a câmera. Um homem atarracado, fuzis entrecruzados ao longo do corpo como um cangaceiro, quase invade, de costas, o campo da imagem. Cena corriqueira que não será captada. A viela, que só pode ser filmada vazia, por contingências da presença armada do tráfico de drogas no morro na época, torna-se um cenário estéril que destitui o faz-de-conta da criança de qualquer potência criativa. O estereótipo imprime-se na cena: de um lado, o pesquisador que filma, do outro, $o$ pesquisado que executa aquilo que imagina que o pesquisador deseja filmar.

Os pontos de vista não se abalaram. Cada um permanece acantonado no seu papel predefinido: nenhum escape, nenhum encontro.

Bate-papo. A cada retorno ao campo, encontramos um grupinho de quatro crianças, entre 9 e 12 anos, que frequentam as aulas de Mestre-sala e Porta-bandeira. Sempre dispostas a conversar conosco, descrevem acontecimentos ocorridos no morro e na Escola de samba durante nossa ausência. Constróem pouco a pouco histórias e narrativas ricas em detalhes e imagens.

Um dos garotos nos conta que um menino, vendo um montinho de dinheiro em cima da mesa de sua casa, apanhou algumas notas tomando o cuidado de não desfazer o pacote. Com um franco e prazeroso sorriso, o garoto narrador continua sua história explicando que, com esse dinheiro, o menino comprou balas, foi ao fliperama, à Lan house etc. Voltando para casa, o menino encontrou o padrasto que, enfurecido, deu nele, colocou dois ovos quentes nas suas mãos, queimou com colher quente, porque o dinheiro era da "boca". ${ }^{2}$ Quando os bandidos souberam do acontecido foram lá, bateram no padrasto e explicaram: "criança a gente só pode fazer bem, quanto mais a gente dá, mais a gente recebe". Essa frase, repetida várias vezes pelo garoto narrador, torna-se moral da história de um verdadeiro conto.

Conversa vai, conversa vem. Sintonizar-se, en passant, nesse movimento e rastrear algumas histórias narradas aqui. Entrever como elas desenham outros territórios em que a violência não está fixada em determinados atos ou pessoas que as encarnariam. A violência desliza entre seus protagonistas instaurando outras lógicas. Nesta história, migra para um campo quase mágico, o do jogo do toma-lá-dá-cá dos gêmeos Cosme e Damião ou dos erês, entidades-criança do universo religioso afro-brasileiro para as quais são oferecidos doces e guloseimas em troca de serviços e pedidos os mais diversos: "quanto mais a gente dá, mais 
a gente recebe". A criança, objeto de violências físicas, vítima do entorno social, surge como protagonista de um novo enredo podendo adquirir, como Cosme e Damião, a potência de retribuir o que lhe é oferecido.

Uma brecha. Propomos a este grupinho uma brincadeira: desenhar. Ficou acertado que começaríamos essa brincadeira na laje da casa de um deles.

\section{INVENÇÃO COLETIVA DE UMA METODOLOGIA}

A escolha do lúdico como direção da pesquisa, não implicava a adoção de um método constituído de antemão. Nosso desafio aqui, como sugere Eduardo Passos e Regina Benevides de Barros (2009, p. 17), era o de "realizar uma reversão do sentido tradicional de método - não mais um caminhar para alcançar metas pré-fixadas (méta-hódos), mas o primado do caminhar que traça, no percurso, suas metas".

No primeiro encontro propusemos, no início, um quadro espaço-temporal mínimo, como as regras de um jogo que permitiriam começar a brincadeira. Pedimos que desenhassem o que mais gostavam de desenhar colocando a folha na horizontal. Eles teriam uma só folha de papel, por isso o desenho deveria ser caprichado e poderia levar o tempo que fosse, quanto maior o tempo, melhor.

Depois de uma hora de muita concentração e empenho, os primeiros desenhos foram sendo concluídos. A cada um que terminava, sugerimos que descrevesse o seu. Pouco a pouco, uns começavam a comentar os desenhos dos outros. Propusemos, então, que criássemos uma história coletiva para cada desenho individual. Uma contra-proposta, vinda de um dos garotos, surgiu: vamos fazer uma história só com todos os desenhos. Rapidamente, as crianças, de comum acordo, os organizavam numa sequência que de uma certa maneira parecia óbvia e clara para todos. Assim que a primeira frase foi formulada, começamos a anotar num caderno a história: "Era uma vez um mundo feliz que tinha paz e sossego...". $\mathrm{O}$ ato de escrever provocou-nos um receio, até que ponto ele não quebraria a espontaneidade? Mas o espírito do jogo, já bem instalado, eliminou esse risco. Quando pedíamos que falassem mais devagar, eles se divertiam dizendo: "você anotou essa palavra? Agora anota aí...". Anotar conferia uma certa importância ao que já estávamos perenizando no papel por meio dos desenhos. Quando acabaram a história, propusemos que ela fosse lida em voz alta. Ao fim da leitura, o sentimento alegre de ter conseguido concretizar alguma coisa que agradava a todos explodiu em aplausos, gritos e risos! Emergia ali o plano de consistência para um diálogo nascente. Quiseram que relêssemos mais duas ou três vezes. Alguns intervinham na modificação de uma ou outra palavra que se repetia, o que demonstrava o resultado positivo da preparação feita no intuito de conquistar um engajamento efetivo das crianças naquela brincadeira. Nos nossos vários encontros que se seguiram, os temas dos desenhos, as modalidades de invenção das histórias e as regras do jogo variaram em função do cruzamento de olhares e desejos de cada um. Essas sessões de desenho proporcionaram a construção gradual de uma metodologia de trabalho que pressupõe a participação ativa das crianças em encontros operados no campo de uma pesquisa na qual observador e observado 
tornam-se parceiros de interrogações mútuas e recíprocas. As correções dos textos, a escolha dos temas dos desenhos, diziam respeito também ao que poderia ou não sair dali, ao que era possível ou não de se tornar público.

Rapidamente, uma outra brincadeira foi proposta por um dos garotos: filmar os desenhos enquanto um deles leria as histórias. Unanimamente decidimos que as filmagens deveriam ser feitas fora do morro, a presença da câmera ali não seria desejável. "É por causa das câmeras, esse é o problema. As pessoas vão pensar que a gente tá filmando o morro", explicaram. Sessões de desenho e filmagens foram então sendo realizadas de maneira alternada. Com o passar do tempo, a brincadeira tornou-se "trabalho", o nosso, o que fazemos juntos. Essa passagem da brincadeira ao trabalho não significava uma abolição do lúdico, pelo contrário, acrescentava um novo laço. "Nosso trabalho" ocupava agora vários territórios: dos desenhos e histórias, das filmagens e conversas que estes provocavam, de um filme, de um trabalho compartilhado que seria apresentado na Universidade. Pouco a pouco, montávamos, sempre de maneira coletiva, um dispositivo que permitiria efetuar deslocamentos em vários níveis, a fim de deixar emergir, nos nossos encontros, novas subjetividades.

\section{TrêS DESLOCAMENTOS CONCOMITANTES E INDISSOCIÁVEIS}

Primeiro deslocamento: após várias sessões de desenhos no morro e o registro minucioso das narrativas que os acompanhavam, distanciamo-nos então da Mangueira para poder olhá-la e contá-la diferentemente. Para as filmagens, instalamo-nos na varanda de uma das bibliotecas da Universidade do Estado do Rio de Janeiro (UERJ) que se encontra exatamente em frente ao morro da Mangueira. Dali, lendo as histórias e comentando os desenhos, poderíamos iniciar novas conversas sobre a vida no morro que tínhamos sob nossos olhos.

A este primeiro deslocamento no espaço, precisamos, no entanto, associar um segundo, de uma outra natureza. Para isso, retomamos, como o faz Janice Caiafa (2007, p. 149), a ideia de voyage sur place proposta por Gilles Deleuze e Félix Guattari (1972). Esta viagem sur place é uma viagem que não implica um movimento, mas uma relação com a diferença. Acolher o outro pressupõe de fato um deslocamento de si mesmo. A experiência etnográfica na qual nos encontramos não se define mais pela interrelação de duas subjetividades já constituídas. Nessa viagem sur place, nesse deslocamento de si mesmo, na sua própria desterritorialização, o antropólogo encontra um outro igualmente desterritorializado por essa conexão, esse agenciamento de elementos heterogêneos. As subjetividades não estão constituídas de antemão. Nesse agenciamento, bifurcamos da ideia de intersubjetividade para a de produção. A relação dialógica torna-se, então, produtora de subjetividades: antropólogo e "antropologizado" entram num devir-outro criador de novas significações. É por intermédio dos suportes imagéticos (desenhos, histórias e vídeo) que antropólogas e crianças puderam deslocar-se de si mesmas para ocupar outros territórios. O produto desse encontro, as subjetividades que emergem dali, são coletivas e polifônicas. 
Para poder percorrer juntos esses novos territórios, devemos efetuar um terceiro deslocamento, dessa vez na temporalidade fictícia do "era uma vez", do "por exemplo", do "como se". Seguindo a ideia de Jean Rouch, segunda a qual "fazendo como se, ficamos mais próximos da realidade" (MOSSO..., 1997), a ficcionalização, intrínseca aos territórios balizados pelas imagens e histórias das crianças, não se opõe à realidade. É justamente por meio da construção de um "real imaginado" (GONÇALVES, 2008), oriundo de suas fabulações, e graças ao desvio que estas propõem, que o processo de construção da própria realidade foi tocado.

\section{UMA CARTOGRAFIA FRAGMENTÁRIA}

Era uma vez um mundo feliz que tinha paz e sossego. Tinha muita limpeza.

Era uma vez uns morros longe do Rio de Janeiro que tinha muitos animais como cavalo, galinha, porco.

Daqui uns dias, o Rio de Janeiro começou a se afundar, o sol fugindo e as nuvens estavam ficando muito azuis porque todo mundo sabia que era inverno.

Daqui a duas semanas, o mundo foi se acabando, porque estava começando a poluição: falta de comida, falta de água, plantas morrendo de seca.

Daqui a cinco dias, começou a guerra no Rio de Janeiro. Os bandidos queriam invadir o exército, muita gente inocente morrendo que não tinha nada a ver com a história e os traficantes que não tinham coração. Morreram duas crianças, dois feridos e uma mãe grávida morta. Fim de "guerra no Rio de Janeiro".

Esta história, composta coletivamente no primeiro encontro, dá o tom à experiência da pesquisa e aos percursos que nos levaram à realização do filme $(\mathrm{O}$ MORRO..., 2010): recitamos, de uma palavra, de um pedaço de frase, de um pequeno traço hesitante, ou de uma cor a outra, o mito da cidade próspera e feliz que declina pouco a pouco no sofrimento. Ao mito do esplendor do Rio de Janeiro que se destrói será associado, em outros momentos, o mito da Mangueira. Numa tentativa de reorganização de uma outra história que se vai tornando o filme, um dos garotos recolhe os desenhos para colocá-los numa certa ordem e argumenta:

Júnior, tu não tá entendendo o que eu quero fazer: primeiro assim, o Rio de Janeiro era bonito, a Mangueira, as histórias bonitas, aí no final é que vai acabando, assim, as histórias tipo de poluição, o Rio de Janeiro tava se acabando, assim, né Carmen? 
Ao final da leitura dessa história inaugural, um outro garoto mostra para a câmera o primeiro desenho, no qual vemos uma casa azul e rosa traçada com régua. No interior, uma mesa, duas cadeiras e um aparelho de TV estilizados. Fora da casa, duas grandes flores e uma mangueira verde e rosa. No céu, o sol, duas nuvens azuis e grandes pássaros pretos voando entre corações. Alguns os chamam de pavões, outros de urubus: "quando uma pessoa morre, lá na Mangueira, eles dizem que quando uma pessoa morre, fica voando isso aqui no céu". Dirigindo-se à câmera, o garoto diz que "a história tem tudo a ver com o desenho, a gente vê o desenho pensando sempre na história. Faz de conta: como longe do Rio de Janeiro tinha vaca, porco, galinha...tudo é sobre isso aqui, porque isso daqui é uma roça pra gente". Um outro agita o último desenho desta série: um sol, duas nuvens azuis, uma mangueira verde e rosa. Um quartel militar delimitado por três linhas verdes traçadas com régua: dentro, armado de um fusil, um soldado de preto. Fora, um tanque preto blindado, sem esteira, com seu armamento de onde jorra um feixe de balas verdes dirigidas a um bandido de verde, este também armado de um fuzil (ou metralhadora?) de onde são atiradas grandes balas verdes em direção ao sentinela a postos numa das duas guaritas sobrepostas à caserna. O Garoto explica: "aquele desenho, aquele lá fala de paz, esse aqui não, esse fala de guerra, bandido, um querendo matar o outro. Aqui, a poesia do menino que escreveu: era uma vez um mundo que tinha guerra, que não tinha limpeza [...]". A potência do devir-outro e a força do coletivo tomaram realmente a frente: autor da poesia e do desenho, ele se autodenomina "o menino". Mesmo se não fosse ele o autor, a formulação "a poesia do menino que escreveu" dilui por si só a autoria de qualquer uma das crianças nesse coletivo, reforça a ideia de que nesse deslocamento de si mesmo, operado no processo da pesquisa, produz-se novas enunciações de subjetividades.

Do mito, deslizamos para a história da fundação do morro e da Escola de samba.

Era uma vez o morro da Mangueira. Eram as casas verde e rosa. Em cima do morro, na Bastião, tinha uma casa de Deus, ao lado, um pé de manga. Embaixo, na rua, tinha um trem construído pelo morro. Muitos anos atrás, no morro, tinha uma grande ferrovia de trem. Construíam trem para a estação da Mangueira e trens para encomendações para os outros países. As encomendações saíam para Alemanha, Uruguai, Estados Unidos e América. Assim, o morro faturou muitos dinheiros e assim, muitos anos à frente, surgiu um novo morro. Novas casas, novas famílias. E essas pessoas pararam de trabalhar na ferrovia. Assim surgiu a Escola de samba da Mangueira.

Sol e nuvens azuis. Num dos desenhos, as casas de todas as cores sobrevoando a estação de trem dividem o céu com pássaros pretos. No outro, as casas são todas verdes ou rosas, como a linha que começa rosa para, próxima da pipa, ficar verde. Ponto de vista aéreo.

Ver a Mangueira de longe permite encará-la de outra maneira. Da biblioteca da UERJ, ela se torna uma paisagem: "daqui ela é tão bonita [...] parece que nem tem tráfico na favela [...]". De um lado, nos diz um garoto: "a paisagem 
daqui parece que dá pra ver tudo [...] dá pra ver os moradores todos, a ponte Rio-Niterói [...]". De outro lado, mais tarde, a ideia de filmar essa paisagem faz surgir uma tensão entre o próximo-distante, o mesmo garoto explica que "para filmar a Mangueira tem de ir de perto [...]". Como resolver essa tensão entre o próximo-distante? Uma das crianças o interrompe abruptamente:

[...] isso é uma história, você tem que entender, tem que botar na cabeça, isso é uma historia. Não é uma realidade, se fosse uma realidade, tudo bem, mas é uma história, como se fosse assim, uma história minha, sua, do Braian, do Júnior, da Carmen, da Sylvie [...] ele não bota na cabeça que isso é uma história, ele pensa que isso daqui é uma realidade, mas não é. Uma realidade é assim, uma casa de verdade dos moradores, o trem que agora tá passando, essas coisas aí [...] Isso é uma história [...] Isso daí que é a realidade.

Justamente, substituindo a questão da distância pela das durações fictícias das histórias: "daqui seis horas", "daqui cinco dias", uma dimensão temporal outra, a dimensão do "era uma vez". Só essa duração fictícia poderia nos deixar entrever esse íntimo-estrangeiro, acolhendo em nós mesmos o diferente, nessa viagem sur place à qual nos convida o "como se".

É no registro do "por exemplo" que a garota nos explica porque, quando for mulher, não quer depender de homem - "por exemplo, ele é traficante, é o vaporzinho, aí ele não arruma dinheiro quase nenhum dia, aí eu vou ficar dependendo dele?" - ou ainda descreve os crimes da polícia e a covardia dos jornalistas em filmar:

Aí, por exemplo, eles estão matando um, um da minha família, aí os repórteres vêm, ao invés de filmar tudo o que tá acontecendo na Mangueira, não, eles filmam só o que os bandidos tão fazendo com os polícia pra mostrar lá na televisão, pros outros ficarem com pena, ao invés de filmar tudo mesmo [...].

Testemunhas das torturas cometidas pelos bandidos ou pelos policiais, as crianças criticam e se revoltam contra as injustiças. Eleva-se o tom, um corta a palavra do outro. Por vezes não conseguem ficar sentadas em torno da mesa para conversar, levantam-se, saem do quadro:

[...] essas histórias é tipo um terror. Os polícia chegam no morro, não chegam pra prender, eles agora estão chegando só pra matar [...] porque as cadeias estão muito cheias, eles não tão vindo pra prender, eles tão vindo pra matar.

A violação do espaço privado do cidadão aparece no simples gesto que mostra como os policiais arrancam o lençol da corda de um morador para carregar os corpos dos mortos: "se tiver lençol dos moradores na corda, eles puxam e botam o corpo do bandido que morreu em cima do lençol e leva pro cemitério [...]". O respeito ao ofício de um médico, já amplamente colocado em questão 
pela sociedade carioca, é aqui justamente defendido. Cada um deveria fazer seu trabalho, jornalistas ou policiais, e deixar os outros cumprirem o seu: por exemplo, não impedir um médico de tentar salvar a vida de um ferido, mesmo que ele seja um traficante. No deslocamento de si mesmos, papéis e funções circulam, outros territórios como o do direito do cidadão são percorridos. Assim também, a própria construção desse "real imaginado", formulação teórica do pesquisador, pôde ser elaborada pela criança que nos adverte que o filme que estamos fazendo é uma história, não é a realidade, mas uma história.

Sábado, 30 de maio de 2009. Encontro marcado na frente da quadra da Escola de samba para subirmos o morro com as crianças. Seguimos ofegantes nossos guias. Faz muito calor, decidimos trabalhar dentro da casa e não na laje como de costume. Somos cinco, um dos garotos não apareceu. Antes de sair de casa, pensamos em propor a leitura de duas músicas de compositores da Mangueira para desencadear um novo processo de construção dos desenhos e narrativas. Aqui, agora com eles, essa proposta parece não fazer muito sentido, tomamos um outro rumo perguntando se eles pensaram em alguma coisa para esse sábado. Um dos meninos diz que sim, mas que não quer falar. O outro insiste e ele propõe numa só palavra: "operação". A concisão da resposta nos deixa em dúvida: "o que é operação?", "operação que teve na Mangueira", ele responde. O outro já antecipa: "vou fazer o cara que morreu". Um dos garotos nos diz que um conhecido quase foi levado pela polícia nesse dia: "ele é bandido mas é bonzinho, ele não faz ruindade pros outros". Sem outras explicações ou delongas, começam logo a desenhar. Aplicam-se em detalhes que são comentados com uma certa excitação. Um dos meninos nos mostra no seu desenho o campo de futebol que conhecemos. Mostra a vala que passa pelo pé de uma árvore: "vou fazer o cara aqui na vala". "Mas ele não morreu com o pé na vala, foi com a cara na vala", explica a garota que avisa: "vou fazer o mesmo desenho contando outra história". Os três discutem os mínimos detalhes: "o helicóptero pousou assim na pedra", "polícia usa chapéu?", "alguns sim", "bota capuz", "capuz é X9". ${ }^{3}$ Mostrando o desenho: "os garotos ficaram sentados com a perna virada pra vala, em cima do muro. Os de preto é só polícia, os moradores são de azul", "aqui tá os carros de polícia e os moradores tudo chorando". Entusiasmada, a menina diz mais uma vez: "tô contando outra história"; um outro pontua: "o que aconteceu na vida real, mas contando outra história".

O campinho de futebol, a pequena mesa e as cadeiras de cimento ao lado do balanço na pracinha logo abaixo. Uma casa, os moradores saindo amedrontados, a polícia atirando do helicóptero na direção deles [...] As escadas pelas quais os policiais descem dos telhados, suas armas, as balas, os helicópteros, a vala com a cabeça do bandido morto ensanguentado, seus parentes que se lamentam, as crianças sentadas em cima do muro. O morto coberto de sangue cercado por sua família suplicante enquanto uma corda puxa seu corpo que, como uma simples trouxa, será alçado em direção a um helicóptero verde. De um lado e de outro, duas casas rosas e duas nuvens muito azuis habitam a cena, enquanto dois sóis, o da manhã e o do fim da tarde, a situam: tudo isso num só dia! 
Variações sobre um tema. No filme, escolhemos para o som de "Operação", como eco ou resposta, o metralhar dos tamborins, os estrondos do surdo e o alerta das caixas e repiques. Caleidoscópio de fragmentos de cenas que se diferenciam na sua repetição, "Operação" foi editada numa história de três "era uma vez", sempre prestes a recomeçar:

Era uma vez "operação de assustar".

Era uma vez, ao nascer do sol, os polícia chegou no morro da Mangueira.

Era uma vez a operação, ninguém sabia o que ia acontecer.

Todo mundo tava jogando futebol no campinho aí veio o águia. ${ }^{4}$ Todo mundo saiu correndo. Assim, eles deram tiro em cima de trabalhador. Um foi preso e um morreu. Todo mundo ficou assustado. O sol tava raiando e os polícia não queriam saber de nada. Eles queriam sair matando. Os moradores escutou os tiros e um grito de uma pessoa, quando os moradores foi ver era mais um bandido que estava morto no chão. Os moradores ficou apavorado quando os polícia chegaram dando tiro, gritando e o helicóptero veio pra dar cobertura para os polícia, aí mandou dar mais tiro pro alto e o criminoso morreu com a cara na vala com oito tiros. $\mathrm{Na}$ Mangueira, passou um helicóptero, aí passou um bandido cheio de drogas na bolsa. Aí um polícia armado viu o bandido, atirou no bandido, ele caiu no chão, aí foi tentando abrir os olhos mas não dava mais. As famílias dele, desesperadas, chorando. O helicóptero soltou a corda e pegou o morto. A família dele gritando: "não, não, não leva". Tava um sol lindo, uma nuvem azulzinha e o helicóptero puxou a corda e levou ele, assim acabou a história.

O garoto que não compareceu no encontro daquele sábado escolheu lê-la. No dia da gravação dessa leitura ele comenta: "ah, eu me lembro desse desenho que eu fiz, ficou muito maneiro!". Não é a autoria, dissolvida no coletivo, que é reivindicada aqui, mas a expressão de um desejo: a participação mesmo na ausência.

\section{TraÇAR LiNHAS: DAR UM RITMO (CARTOGRAFAR)}

Título: "A noite e o dia na Mangueira"

O esporte na Mangueira é o campo de futebol, todo mundo joga, crianças e adultos. A igreja estava orando por Deus, pedindo a Deus que nada falte no dia-a-dia. Daqui a seis horas, um homem estuprou uma menina de seis anos. Botaram ele no balde de gari, deram muitos tiros nele, tacaram gasolina e álcool e fósforo e começou a pegar o fogo. Depois, daqui 
a seis horas, teve rua fechada, dia de domingo com pagode e funk. E uma mulher pensou que outra queria o marido dela que era traficante. As duas começaram a brigar, a mulher dele saiu cheia de sangue e ele puxou o cabelo da outra que brigou com a mulher dele.

No verso da folha de papel, bem embaixo à esquerda, praticamente no cantinho, dois corpos sobrepostos: o de um pequeno homem verde e o de uma miudinha menina rosa. O garoto que começara esse desenho renuncia: "é muito difícil desenhar isso". Ele vira a página e a divide em quatro quadros para compor "A noite e o dia na Mangueira". Do lado esquerdo, o dia: no quadro de cima, o futebol, no de baixo, a missa. Do lado direito: a noite. No alto, suspensos sobre duas pedras, dois homens armados atiram balas verdes na direção de um homem enfiado de cabeça para baixo numa grande lata de lixo ; ao lado, uma criança rosa, que assiste a cena, chora. No último quadro do desenho, três figuras protagonizam a briga no pagode e no funk: duas mulheres com seus cabelos compridos e um homem portando uma corrente com medalha no pescoço, a mão esquerda empunha um fuzil e com a mão direita, ele puxa o cabelo de uma das mulheres.

Um outro garoto, numa sessão posterior, faz um desenho, dividido verticalmente em duas partes, que mostra: do lado esquerdo, sob um sol risonho de boné e pássaros pretos, o chefe dos índios à cavalo. Figura que lembra de muito perto os jovens do morro cavalgando enormes motos (ou as crianças que os imitam de bicicleta), traçando velozes pela rua principal, na contra-mão, intimidando os que por ali passam. Ao lado dele, um homem fuma um cachimbo; xamã ou carrasco? Mais adiante, um objeto, com a palavra "machado" que o designa, perto do supliciado estendido sobre uma espécie de mesa verde. Do lado direito, cenas da vida cotidiana sob duas tendas pintadas de rosa, como todos os personagens: duas crianças, uma mãe e seu bebê. Do lado de fora, um homem munido de um leque.

Era uma vez a tribo dos índios. Na mesa do machado, o traidor estava sendo arrancada a cabeça só porque ele traiu a tribo. O cacique, no cavalo, passava. E o traidor era apanhado com machados e chicote. Muitas das vezes, o corpo estragou, começou a desmanchar porque já estava fedendo. $\mathrm{Na}$ tribo, dois irmãos comendo ilegalmente pão e bolo de milho. Na outra, a mãe fazendo comida no panelão e fazendo seu bebê dormir na rede. E o chefe da tribo "saturando" a chuva e "saturou" errado e "saturou" o vento. Fim da história. Índio de novo.

Dia e noite, noite e dia. O cotidiano banaliza e coloca num mesmo plano a violenta punição do estuprador de uma criança e a briga entre duas mulheres. Justiças injustas ou injustiças justas às quais faz eco o cotidiano de uma tribo de índios onde se arranca a cabeça "só" porque foi cometida uma traição. O deslocamento para o universo dos índios desencadeia deslizamentos na linguagem 
provocando outros sentidos: quando se "satura" errado a chuva acaba-se "saturando" o vento e as crianças, quando comem o banal pão e bolo de milho, o fazem ilegalmente. No final, como o dia e a noite, tudo recomeça: índio de novo.

Fim da história, fim da guerra, em seguida, era uma vez: deixamo-nos nos levar pelo ritmo das horas, dos dias, dos carnavais. Esse tempo cíclico escande tanto as narrativas quanto a vida no morro. Todos os anos, com a aproximação do carnaval, o verde e rosa inunda as vielas da Mangueira. A mesma coisa acontece nos desenhos quebrando qualquer dicotomia que reservaria essas duas cores à Escola de samba e imporia aos desenhos representando os traficantes o vermelho da facção criminosa que, naquela época (e, de maneira mais discreta, ainda hoje em tempos de Unidade de Polícia Pacificadora - UPP) dominava o tráfico de drogas e impunha sua lei no morro. Se o preto, cor da polícia civil e do Bope que invadiam regularmente o morro, é quase sistematicamente o privilégio da polícia, do exército e dos urubus-pavões, vemos o verde e rosa, cores emblemáticas da Escola de samba, ganhar o terreno colorindo as cenas e atenuando fronteiras: a porta-bandeira verde é cortejada pelo mestre-sala rosa, balas verdes e rosas jorram de fuzis, casas verdes e casas rosas povoam o morro, um traficante verde mata uma craqueira rosa, um bandido segura um fuzil rosa [...] A associação dessas duas cores, verde e rosa, é como um motivo, verdadeiro ritornelo que dá o tom ritmando um território existencial: "Mangueira é uma mãe, Mangueira é uma mãe [...]", esse é o refrão do "Rap da Estação Primeira de Mangueira" composto pelas crianças para a abertura do nosso filme $O$ morro da Mangueira como é. Imbricação inextricável da escola de samba no morro em que as crianças participam dos ensaios e desfiles da Escola. Pequenos Mestres-sala, Rainha da bateria ou Porta-bandeira verde e rosa, um gostaria de falar mais do carnaval, o outro do morro. Um terceiro divide para acrescentar:

[...] a maioria no morro, quase todo mundo desfila, mas sendo que a quadra não é dentro do morro, assim, no meio do morro, não, ela fica mais embaixo, na porta do morro, ela que faz a abertura, ela que faz a abertura da Mangueira. Porque sem a Escola de samba, o morro fica chato.

De fato, a quadra, o Palácio do Samba, construção imponenente, sinaliza o morro tanto quanto o oculta. Tudo se cruza, nada se fecha em si mesmo: nem "nós" nem "eles" instituídos, nem polo do "bem" ou do "mal" constituídos.

Aprendizes de cartógrafos, seguimos as crianças, nossos guias, no labirinto de seu morro, deixamo-nos afetar pela intensidade de uma cor, a fragilidade de uma palavra, a poesia de uma história, compomos com eles esse caleidoscópio, sempre precário, prestes a balançar na direção de outras imagens. Sua maneira de estar no mundo, de viver o que lhes sobrevém, assemelha-se muito com o jeito como caminham no morro, pulando de um degrau para o outro, escorregando ao longo de estreitos corredores, às vezes mesmo de perfil de tão exíguos, descendo ruelas sinuosas, parando de repente para esboçar um sinal, transmitir em voz baixa uma mensagem ou gritar um pedaço de frase. Repartem e já desaparecem, onde bifurcaram? Paola Berenstein Jacques (2007, 
p. 66) fala desse labirinto no qual não se caminha nunca em linha reta e a cada curva "vai se descobrindo um ritmo de caminhar diferente imposto pelo próprio percurso das vielas. É o que se chama ginga".

Assistimos ao filme com eles pela primeira vez no Campus da Praia Vermelha da Universidade Federal do Rio de Janeiro (UFRJ) em companhia de Paulo Vaz, que nas nossas conversas chamávamos de "o professor". Risos e zombarias entre uns e outros quando se viram bem menores, alguns trocando os dentes, outros ainda não sabendo dançar muito bem. Nosso trabalho, como as histórias, poderá estar sempre recomeçando. O filme, enquanto objeto finito, despertou nas crianças a mesma expectativa dos efêmeros desfiles de carnaval: "e pro ano que vem, o que a gente vai fazer?". Comentários suscintos e a dispersão para uma certa curiosidade em conhecer essa Faculdade que, afinal, sempre esteve presente nos nossos encontros. Após a projeção, o professor sugeriu um passeio pelos corredores do histórico prédio contando suas sucessivas transformações até se tornar Universidade. A proposta para um lanche no campus completava o prazer da descoberta do lugar. $\mathrm{Na}$ saída do prédio principal, as crianças descem a escada esboçando passos que marcam o compasso de um canto que começa timidamente. A travessia do jardim até a lanchonete vai, pouco a pouco, transformando-se num desfile de Escola de samba coreografado pelo samba enredo daquele ano que elas cantam a plenos pulmões. Que sejam quatro mil componentes na Sapucai ${ }^{5}$ ou quatro crianças ali, até uma única pessoa bastaria, quando "eu sou Mangueira", "a Mangueira chegou".

A ginga dessas crianças é uma questão de estilo. Percorrendo esse território instável, pegamos no ar seus sonhos, suas revoltas, suas resistências, seus desejos. Sem se deixar enfeudar ou reduzir a nenhuma representação consensual as crianças circulam entre, atravessam. Rebeldes, dissidentes, elas nos propõem essa cartografia imaginada, fragmentária, na qual se desenham linhas de fuga onde alguma coisa passa: a potência do devir no lugar de um futuro anunciado incerto. Como o garoto que insiste em nos explicar:

[...] eu não posso falar nada porque eu não sei meu dia de amanhã, se eu posso ser um traficante ou um trabalhador...mas eu penso assim, em ser um bombeiro, eu não posso falar nada dos outros porque eu não posso pensar o dia de amanhã, como vai ser, eu posso ser um traficante ou um trabalhador $[\ldots]$.

\section{Notas}

Morro e Escola de samba do Rio de Janeiro onde desenvolvemos nossa pesquisa de campo de pós-doutorado que contou com o apoio do CNPq e Faperj e a supervisão de Janice Caiafa e Paulo Vaz (UFRJ-ECO).

Boca: ponto de venda de drogas.

X9: delator.

${ }^{4}$ Águia: helicóptero da polícia.

${ }^{5}$ Avenida Sapucaí onde são realizados os desfiles de carnaval, conhecida também como sambódromo. 


\section{REFERÊNCIAS}

PASSOS, E.; BENEVIDES DE BARROS, R. A cartografia como método de pesquisa-intervenção. In: PASSOS, E.; KASTRUP, V.; ESCÓSSIA, L. (Org.). Pistas do método da cartografia: pesquisa-intervenção e produção de subjetividade. Porto Alegre: Sulina, 2009. p. 17-31.

BIRMAN, P. Spectacle de la violence et construction de la peur au Brésil. Revue Chimères, Paris, n. 51, p. 69-81, 2003.

CAIAFA, J. Aventura das cidades: ensaios e etnografias. Rio de Janeiro: FGV, 2007.

DELEUZE, G.; GUATTARI, F. L'anti-CEdipe. Paris: Minuit, 1972.

GONÇALVES, M. A. O real imaginado: etnografia, cinema e surrealismo em Jean Rouch. Rio de Janeiro: Topbooks, 2008.

JACQUES, P. B. Estética da Ginga: a arquitetura das favelas através da obra de Hélio Oiticica. Rio de Janeiro: Casa da Palavra, 2007.

O MORRO da Mangueira como é. Direção: Carmen Opipari e Sylvie Timbert. HD (52 min), Rio de Janeiro: [s.n.], 2010. Distribuição: opiparitimbert@hotmail. com.

MOSSO, mosso - Jean Rouch Comme si... Direção: Jean-André Fieschi. França: [s.n.], 1997. Episódio de TV (73 min), documentário.

VAZ, P. Vítima virtual e medo do crime. Trajectos-Revista de Comunicação, Cultura e Educação, Lisboa, v. 7, p. 95-106, 2005.

Recebido em: 09 de maio de 2013 Aceito em:10 de julho de 2013 
